\title{
UNCERTAINTIES OF THE ${ }^{137}$ Cs TECHNIQUE FOR VALIDATION OF SOIL REDISTRIBUTION MODELLING IN A SEMIARID MESO-SCALE WATERSHED
}

\section{PEDRO H. A. MEDEIROS ${ }^{1}$, JOSÉ CARLOS DE ARAÚJO², AVACIR C. ANDRELLO ${ }^{3}$}

ABSTRACT: Scarcity of long-term series of sediment-related variables has led watershed managers to apply mathematical models to simulate sediment fluxes. Due to the high efforts for installation and maintenance of sedimentological gauges, tracers have been pointed out as an alternative to validate soil redistribution modelling. In this study, the ${ }^{137} \mathrm{Cs}$ technique was used to assess the WASA-SED model performance at the Benguê watershed $\left(933 \mathrm{~km}^{2}\right)$, in the Brazilian semiarid. Qualitatively, good agreement was found among the ${ }^{137}$ Cs technique and the WASA-SED model results. Nonetheless, quantitatively great differences, up to two orders of magnitude, were found between the two methods. Among the uncertainties inherent to the ${ }^{137} \mathrm{Cs}$ technique, definition of the reference inventory seems to be a major source of imprecision. In addition, estimations of water and sediment fluxes with mathematical models usually also present high uncertainty, contributing to the quantitative differences of the soil redistribution estimates with the two methods.

KEYWORDS: ${ }^{137}$ Cs, soil redistribution, sediment modelling, semiarid.

\section{INCERTEZAS DA TÉCNICA DE ${ }^{137}$ Cs PARA A VALIDAÇÃO DA MODELAGEM DE REDISTRIBUIÇÃO DE SOLO EM UMA BACIA SEMIÁRIDA DE MESOESCALA}

RESUMO: A escassez de séries extensas de dados sedimentológicos tem levado gestores de bacias hidrográficas a aplicar modelos matemáticos para simular os fluxos de sedimentos. Devido aos esforços elevados para instalação e manutenção de estações sedimentológicas, marcadores têm sido apontados como alternativa para validar a modelagem de redistribuição do solo. Neste estudo, a técnica de ${ }^{137} \mathrm{Cs}$ foi utilizada para avaliar o desempenho do modelo WASA-SED na bacia hidrográfica do Benguê $\left(933 \mathrm{~km}^{2}\right)$, no semiárido brasileiro. Qualitativamente, boa concordância foi encontrada entre a técnica de ${ }^{137} \mathrm{Cs}$ e os resultados do modelo WASA SED. No entanto, quantitativamente, grandes diferenças, de até duas ordens de grandeza, foram obtidas entre os dois métodos. Entre as incertezas inerentes à técnica do ${ }^{137} \mathrm{Cs}$, a definição do inventário de referência é uma importante fonte de imprecisão. Além disso, estimativas de fluxos de água e sedimento com modelos matemáticos, geralmente, também apresentam elevado grau de incerteza, contribuindo para as diferenças quantitativas das estimativas de redistribuição do solo pelos dois métodos.

PALAVRAS-CHAVE: ${ }^{137} \mathrm{Cs}$, redistribuição de solo, modelagem sedimentológica, semiárido.

\section{INTRODUCTION}

Studies related to erosion and sediment transport present, as a key difficulty, the scarcity of long term series of reliable data. This fact can be related to the simpler and cheaper way of performing computer simulations using data generated by other researchers. In Brazil, the sediment monitoring network officially registered in the Hydrological Information System of the National Water Agency (Agência Nacional de Águas - ANA) is still incipient, and even on the existing stations, only few sediment concentration records are available.

\footnotetext{
${ }^{1}$ Eng $^{\circ}$ Civil, Prof. Doutor, Instituto Federal de Educação, Ciência e Tecnologia do Ceará, Maracanaú - CE, Fone: (85) 3878-6358, phamedeiros@ifce.edu.br

${ }^{2}$ Eng $^{\circ}$ Civil, Prof. Doutor, Depto. de Engenharia Agrícola, Universidade Federal do Ceará, Fortaleza - CE, jcaraujo@ufc.br

${ }^{3}$ Físico, Prof. Doutor, Depto. de Física, Universidade Estadual de Londrina, Londrina - PR, acandrello@uel.br

Recebido pelo Conselho Editorial em: 16-5-2012

Aprovado pelo Conselho Editorial em: 18-11-2013
} 
Given this limitation, the quantification of erosion processes, sediment transport and deposition has been performed with the use of computer simulation models. Sedimentological models are intended to estimate erosion and sediment yield in ungauged regions, to simulate the effects of changes in the watershed (land use, for example) in the sediment dynamics, and estimate the spatial patterns of sediment yield.

However, this is not a simple task, since:

- The processes are nonlinear with the spatial scale, preventing the extrapolation of results obtained at a finer scale to the watershed scale;

- Models of erosion and sediment transport use, as input data, water fluxes throughout the watershed, also estimated by modelling, thus increasing the uncertainty in the estimations;

- Scarcity of databases with reliable and long series represents a limitation to the validation of model simulations. When existing, sediment gauges are usually limited to few river sections, preventing an adequate spatially distributed validation of model-based on soil redistribution estimates.

In this context, the ${ }^{137} \mathrm{Cs}$ technique for quantification of soil redistribution stands out as an important tool for validation of the estimates obtained through distributed computational modelling of the sedimentological processes, as demonstrated by WALLING et al. (2003), for instance.

The Cesium-137 $\left({ }^{137} \mathrm{Cs}\right)$, an artificial radionuclide produced by nuclear fission of uranium and plutonium, has been introduced on the globe mainly by thermonuclear tests (ZAPATA \& NGUYEN, 2009). During the tests, the ${ }^{137}$ Cs released into the stratosphere has been distributed globally and precipitated on the earth surface. ZAPATA \& NGUYEN (2009) explain that, as it deposits on the surface, ${ }^{137} \mathrm{Cs}$ moves vertically in the soil profile as a result of infiltration of rainwater and is rapidly adsorbed to the soil matrix. The variation of ${ }^{137} \mathrm{Cs}$ activity with depth is determined by a combination of factors, especially weather conditions and soil moisture at the time of the fallout, its structure, its infiltration rate and the characteristics of soil sorption.

The ${ }^{137}$ Cs technique for the estimation of soil redistribution involves a comparison of the isotope inventory in the sampling points with the reference inventory at the study site, i.e. the inventory expected if the area had not been disturbed. It is assumed that the deposition of ${ }^{137} \mathrm{Cs}$ from the atmosphere occurred uniformly over the study area and it has been completely adsorbed to the soil. Thus, it is possible to infer that the relative loss of the isotope indicates the dominance of erosion, while the gain in relation to the ${ }^{137} \mathrm{Cs}$ reference inventory indicates the occurrence of deposition of sediments labelled with the isotope. To obtain quantitative estimates of erosion and deposition of sediments, it is necessary to apply models that relate the loss or gain of ${ }^{137} \mathrm{Cs}$ with soil redistribution (WALLING \& HE, 1999).

The objective of this study is to apply the ${ }^{137} \mathrm{Cs}$ technique to validate the distributed estimations of sediment yield obtained by modelling in a tropical semiarid watershed in Brazil.

\section{MATERIAL AND METHODS}

\section{Study area}

The study area comprehends the watershed of the Benguê reservoir, located in the semiarid Northeast region of Brazil, Federal State of Ceará (Figure 1).

The watershed, embedded in the Upper Jaguaribe Basin, drains an area of $933 \mathrm{~km}^{2}$ and is controlled by the Benguê reservoir, with a $19.6 \mathrm{hm}^{3}$ storage capacity. Nested to the Benguê watershed is situated the Aiuaba Experimental Watershed (AEW), with an area of $12 \mathrm{~km}^{2}$ controlled by the Boqueirão reservoir, with storage capacity of $60,000 \mathrm{~m}^{3}$. The $\mathrm{AEW}$ has been monitored by the Group of Hydrossedimentological Research of the Brazilian Semiarid Region (www.hidrosed.ufc.br) since 2003 in relation to hydrological and sedimentological variables. The 
AEW is located entirely within the Aiuaba Ecological Station (115 $\left.\mathrm{km}^{2}\right)$, an environmentally protected area managed by the Brazilian government.

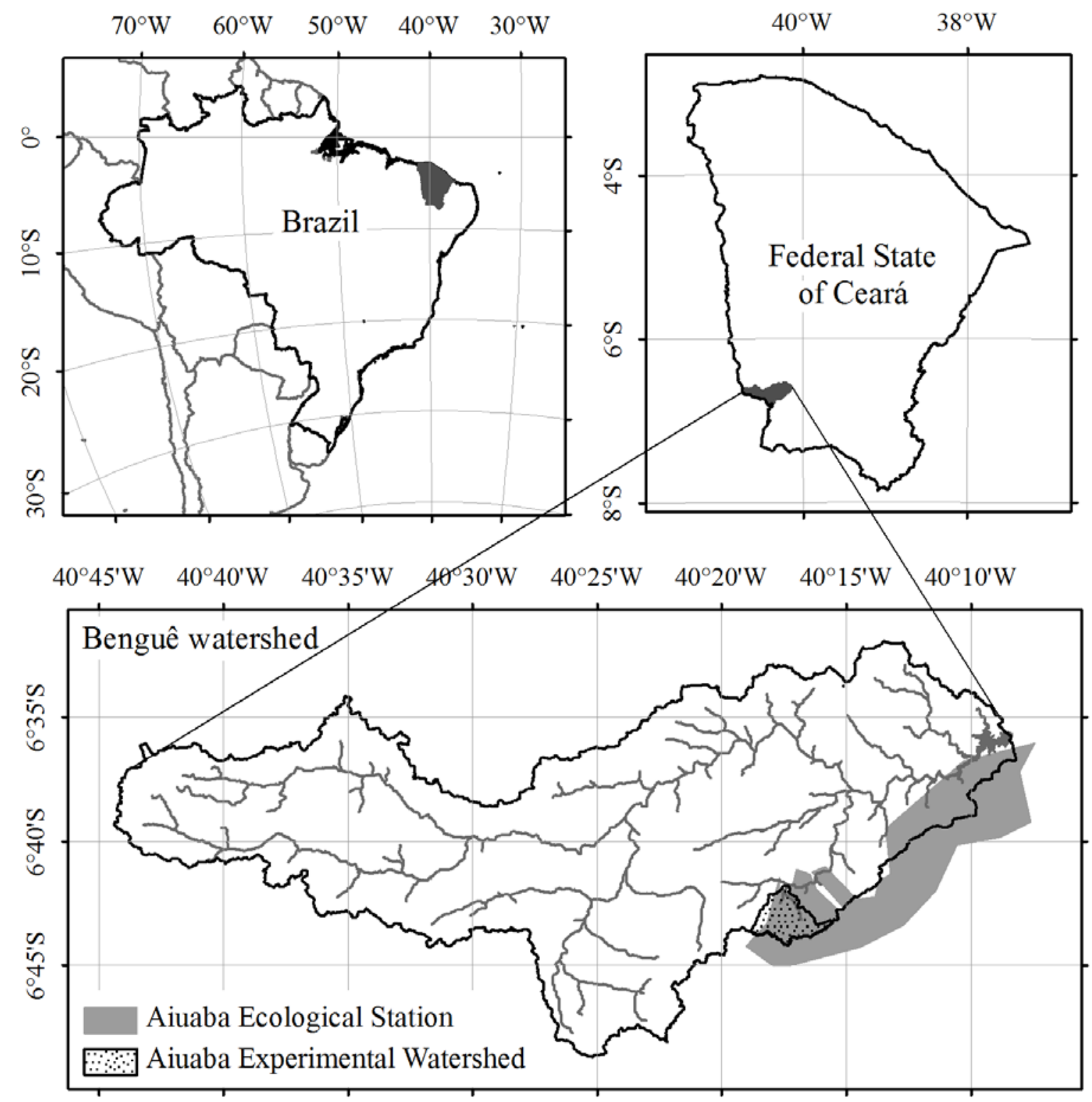

FIGURE 1. Location map of the study area

The climate is tropical semiarid, BS type according to Köppen classification (ARAÚJO \& PIEDRA, 2009), with $580 \mathrm{~mm}$ mean annual rainfall and potential evaporation of approximately 2,500 mm/year, with a high atmospheric water deficit during most of the year. Rainfall is strongly variable over time, with a well defined rainy season (January to May) during which $85 \%$ of the total annual precipitation occur. Convective rainfall prevails, concentrated in a few events of high intensity. Mean annual temperature is $26^{\circ} \mathrm{C}$, with little variation throughout the year: $24^{\circ} \mathrm{C}$ in June and July to $28^{\circ} \mathrm{C}$ in November, with daily temperature ranging from $15^{\circ} \mathrm{C}$ to $35^{\circ} \mathrm{C}$. The relative humidity has an annual mean of $62 \%$.

The natural vegetation is Caatinga, the only unique and typical Brazilian biome for the semiarid Northeast region of the country. As described by MEDEIROS et al. (2009), Caatinga is a tropical xerophytic deciduous vegetation consisting of a mixture of small and medium-sized trees, thorny shrubs and cacti. In the Aiuaba Ecological Station, a physiognomy characterized by relatively sparse shrubs ranging from 5 to 7 meters high dominates, and the occurrence of trees with 
heights between 8 and 10 meters prevails. In areas under human interference, the vegetation has patches of bare soil.

The Benguê watershed is predominantly rural, with a population density of 6.4 inhabitants per $\mathrm{km}^{2}$. Relative to the soil use, the watershed has extensive unexplored areas and sectors with preserved vegetation, such as the Aiuaba Ecological Station. Among the economic activities, rainfed agriculture, specially beans and corn crops, and goat farming stand out. The soil types present in the study area with the main physical characteristics are presented in Table 1 (BRASIL, 1981).

TABLE 1. Physical properties of the soil types present in the study area

\begin{tabular}{llccrc}
\hline \multirow{2}{*}{ Soil type } & \multicolumn{1}{c}{$\begin{array}{c}\text { Location in the } \\
\text { Watershed }\end{array}$} & $\begin{array}{c}\text { Bulk density } \\
\left(\mathrm{g} / \mathrm{cm}^{3}\right)\end{array}$ & \multicolumn{3}{c}{ Texture } \\
\cline { 4 - 6 } & \multicolumn{1}{c}{ \% Sand } & \% Silt & \% Clay \\
\hline Planosols & Northeast portion & 1.2 & 83 & 11 & 6 \\
Latosols & South and west borders & 1.2 & 56 & 10 & 34 \\
Latosols & Southwest border & 1.3 & 79 & 11 & 10 \\
Luvisols & Close to the outlet along the river & 1.4 & 85 & 8 & 7 \\
Luvisols & Central portion & 1.4 & 61 & 20 & 19 \\
Neosols & Central- and northwest portions & 1.2 & 88 & 5 & 7 \\
Neosols & Southeast border & 1.2 & 69 & 23 & 8 \\
\hline
\end{tabular}

Source: Radam Brasil Project (BRASIL, 1981).

\section{The WASA-SED model}

WASA-SED (Model of Water Availability in Semiarid Environments with Sediment Dynamics Component) (FRANCKE et al., 2008, BRONSTERT et al., 2009, MÜLLER et al., 2010) is a deterministic, semi-distributed, continuous simulation model of hydrological and sedimentological processes. To represent the spatial variability of the watershed characteristics (such as topography, soil type and vegetation cover) and the influence on runoff generation, the model adopts a hierarchical spatial discretization of the study area into five scale levels (Bronstert et al., 2009):

- Sub-basin: the basic unit, in which processes of water and sediment transport in rivers and surface reservoirs are calculated;

- Landscape Unit - LU: association of hillslopes with similar sequence of lithology, soil and vegetation. On this scale, the model admits similarities in the vertical and horizontal water fluxes between hillslopes of the same LU;

- Terrain Component - TC: sub-area of a LU with the same position on the hillslope and similar features concerning slope, soil and vegetation. On this unit, lateral surface and subsurface water flow is simulated between TCs with different topographic positions;

- Soil-Vegetation Component - SVC: specific combination of soil and vegetation in a TC, represented by its area fraction within the TC. Lateral redistribution of surface and subsurface runoff is also simulated on this scale;

- Profile: finer spatial scale of the hierarchy. Soil horizons in each SVC are defined on this scale, and water balance is simulated, considering vertical and horizontal fluxes.

In the WASA-SED model, the water balance is initiated on the scale of the soil profile and water transference and flow accumulation are computed to the sub-basin scale. The processes included in the hydrological routines are: interception, evapotranspiration, evaporation of surface reservoirs, infiltration, percolation between soil horizons, sub-surface flow and groundwater storage. Details about the hydrological routines in the WASA-SED model are available at MÜLLER et al. (2010). 
Concerning the sedimentological processes, erosion and sediment transport are simulated in daily intervals. Sediment generation is calculated in the model by the Universal Soil Loss Equation - USLE:

$$
E=E I \quad K \quad L S \quad C \quad P \quad R O K F \quad A
$$

where,
E - erosion (t);
EI - rainfall erosivity factor (MJ mm ha $\left.{ }^{-1} \mathrm{~h}^{-1}\right)$;
$\mathrm{K}$ - soil erodibility factor ( $\mathrm{h} \mathrm{MJ} \mathrm{Mm}^{-1}$ );
LS - slope length and steepness factor (dimensionless);
$\mathrm{C}$ - vegetation cover and crop management factor (dimensionless);
$\mathrm{P}$ - conservation practice factor (dimensionless);
ROKF - factor of rock fragments (dimensionless), and
A - area (ha) of the modelling unit.

The USLE factors are calculated internally in the WASA-SED model as indicated by MEDEIROS et al. (2010).

Equation (1) is applied at the Terrain Component scale and the sediment transfer along the hillslope is then simulated. The process consists of adding the sediment mass transported from upstream $\left(\right.$ Sed $_{i n}$, expressed in $\mathrm{t}$ ) to the sediment mass eroded in the current Terrain Component (E, in $t)$. The mass of available sediment is then compared to the sediment transport capacity $\left(q_{s}\right.$, in $\left.t\right)$ to obtain the sediment yield (SY, t) of the Terrain Component [eq.(2)], which will be transferred downstream.

$$
S Y=\min \left(E+S E D_{i n} ; q_{s}\right)
$$

In the WASA-SED model, the calculation of sediment transport capacity on the hillslopes is based on the Everaert equation (MÜLLER et al., 2010):

$$
\begin{aligned}
& \text { If } \mathrm{D}_{50} \leq 150 \mu \mathrm{m}: q_{s}=1.5010^{-5} \Omega^{1.07} D_{50}^{0.47} \mathrm{~W} \\
& \text { If } \mathrm{D}_{50}>150 \mu \mathrm{m}: q_{s}=3.9710^{-6} \Omega^{1.75} D_{50}^{-0.56} \mathrm{~W}
\end{aligned}
$$

where,

$\Omega$ - effective stream power $\left(\mathrm{g}^{1.5} \mathrm{~S}^{-4.5} \mathrm{~cm}^{-2 / 3}\right)$, calculated internally in the WASA-SED model;

$\mathrm{D}_{50}$ - median particle diameter $(\mu \mathrm{m})$, estimated from the size distribution of the eroded soil, and

$\mathrm{W}$ - width of the Terrain Component (m).

The effective stream power is calculated by the expression:

$$
\Omega=(\rho g q s)^{1.5} / d^{2 / 3}
$$

where,

$$
\begin{aligned}
& \rho \text { - water density }\left(\mathrm{g} \mathrm{m}^{-3}\right) \text {; } \\
& \mathrm{g} \text { - gravity acceleration }\left(\mathrm{m} \mathrm{s}^{-2}\right) \text {; } \\
& \mathrm{q} \text { - surface runoff per unit width }\left(\mathrm{m}^{3} \mathrm{~s}^{-1} \mathrm{~m}^{-1}\right) \text {; } \\
& \mathrm{s} \text { - ground slope }\left(\mathrm{m} \mathrm{m}^{-1}\right) \text {, and } \\
& \mathrm{d} \text { - the runoff depth }(\mathrm{cm}) \text {. }
\end{aligned}
$$

Sediment that leaves a Terrain Component "i" is divided into a fraction moved to the next downstream Terrain Component $\left(\operatorname{Sed}_{\mathrm{in}, \mathrm{TCi}+1}\right)$ and a fraction that is transferred directly into the river 


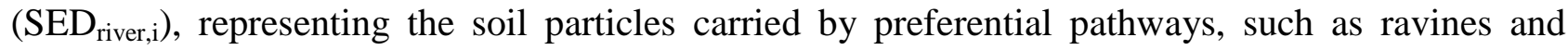
gullies. Such allocation is performed based on the area fraction of the Terrain Component $\left(\alpha_{\mathrm{i}}\right)$ within the respective Landscape Unit, applying the following equation:

$$
\begin{aligned}
& S E D_{i n, T C i+1}=S Y_{i}\left[1-\left(\alpha_{i} / \sum_{n=i}^{n T C} \alpha_{n}\right)\right] \\
& S E D_{\text {river }, i}=S Y_{i}\left(\alpha_{i} / \sum_{n=1}^{n T C} \alpha_{n}\right)
\end{aligned}
$$

where,

$\mathrm{i}$ and $\mathrm{i}+1$ - indices of the current and the next downstream Terrain Components, respectively; $\alpha$ - area fraction of the Terrain Component, and

nTC - number of Terrain Components in the respective Landscape Unit.

\section{The ${ }^{137}$ Cs Technique}

The ${ }^{137}$ Cs technique was used for validation, in a spatially distributed manner, of the WASASED model estimations of soil redistribution on the Benguê watershed. A daily, semi-distributed simulation of sediment yield on the watershed was performed for the period of 1963 to 2008 . Details on the WASA-SED model parameterization can be obtained at MEDEIROS et al. (2010). The modelled period (1963 to 2008, comprising 16,802 days) corresponds to that since the peak of ${ }^{137} \mathrm{Cs}$ fallout until the year of soil sampling. Thus, a direct comparison between soil redistribution modelled with WASA-SED and estimated with the ${ }^{137} \mathrm{Cs}$ technique was possible.

To assess erosion and sediment deposition in specific hillslopes of the Benguê watershed, soil samples were collected in the year 2008 and analysed concerning the ${ }^{137} \mathrm{Cs}$ inventory for comparison with the reference inventory.

The reference inventory can be obtained through a historical record of ${ }^{137} \mathrm{Cs}$ fallout in the study area, by updating the activity expected for the year of soil sampling based on the known decay rate. However, direct records of atmospheric deposition are rarely available, and the adoption of measures undertaken in other regions of the Earth is problematic due to spatial variability of ${ }^{137}$ Cs precipitation.

The difficulty of obtaining the reference inventory of ${ }^{137}$ Cs from direct measurements has led researchers to use indirect methods to define the activity of reference. In the Bengue watershed, the ${ }^{137} \mathrm{Cs}$ reference inventory was determined from soil samples taken in areas admitted stable, i.e. with negligible erosion or deposition since the peak of ${ }^{137} \mathrm{Cs}$ fallout. The ${ }^{137} \mathrm{Cs}$ activity detection was performed by gamma spectrometry analysis, with a coaxial type HPGe detector $-10 \%$ intrinsic efficiency. Details on the experimental design can be found on ANDRELLO et al. (2004). Quantification of erosion and sediment deposition at the study hillslopes with the ${ }^{137}$ Cs technique was carried out by the use of the Proportional Model, which relates soil redistribution with the loss or gain of the isotope in relation to the reference inventory (WALLING \& HE, 1999). In this model, it is assumed that there is a complete mixing of ${ }^{137} \mathrm{Cs}$ in the top soil layers, and that the lateral soil redistribution is directly proportional to the distribution of the isotope. Therefore, the Proportional Model is indicated for areas under tillage, for which a uniform vertical distribution of ${ }^{137} \mathrm{Cs}$ on the soil profile is expected.

Even though there is no evidence that all the studied hillslopes at the Benguê watershed have been used for agricultural purposes, the adoption of the Proportional Model seemed reasonable, because: I) Two of the three samples analyzed incrementally with depth showed a uniform vertical distribution of ${ }^{137} \mathrm{Cs}$ (see Figure 3); II) The vertical distribution may vary considerably in the study watershed due to the soil properties in the different sectors, and no data was available for identification of this pattern in each of the studied hillslopes. 
As presented by WALLING \& HE (1999), the Proportional Model estimates erosion/deposition by the following equation:

$$
Y=10 \frac{B d X}{100\left(t_{1}-t_{0}\right)}
$$

where,

$\mathrm{Y}$ - mean erosion rate $\left(\mathrm{t} \mathrm{ha}^{-1} \mathrm{year}^{-1}\right)$;

$\mathrm{t}_{1}$ - year of soil sampling (2008, in this study);

$\mathrm{t}_{0}$ - year of peak ${ }^{137}$ Cs fallout (1963, according to WALLING \& HE, 1999);

$\mathrm{X}$ - percentage reduction of the ${ }^{137} \mathrm{Cs}$ inventory in relation to the reference inventory, and

$\mathrm{B}$ - soil dry bulk density $\left(\mathrm{kg} \mathrm{m}^{-3}\right)$ and $\mathrm{d}$ is the depth of soil tillage $(\mathrm{m})$.

To determine the ${ }^{137} \mathrm{Cs}$ reference inventory in the study area, three samples were collected in increments from 2 to $10 \mathrm{~cm}$. This incremental sampling also allowed the identification of the ${ }^{137} \mathrm{Cs}$ vertical distribution in the soil. In order to capture a possible spatial variability in the ${ }^{137} \mathrm{Cs}$ reference inventory in the study watershed, the three reference samples were collected at different locations, two in the southern portion of the watershed (R1, Aiuaba Experimental Watershed and R3 on the southern edge of the Benguê watershed) and one in the western portion (R2) (see Figure 2). In addition, a depth-integrated analysis of sample R3 was performed in duplicate for verification.

The three sites expected to be reference concerning the ${ }^{137} \mathrm{Cs}$ inventory, are naturally vegetated and infrequently accessed by people: R1 is situated within the Aiuaba Ecological Station and only accessible to the Ecological Station personnel; R2 and R3 are distant from human settlements. The sampling sites are also situated above soils with relatively high hydraulic conductivity, where the low runoff coefficient can be confirmed by the lack of a well-defined drainage system. This characteristic suggests that the erosive processes are not significant in these areas and, therefore, the inventories should be representative of the reference in the region.

Soil sampling for the soil redistribution estimations was conducted in two stages, using different criteria. Initially, an individual soil sampling procedure (hereafter named ISS) was carried out, i.e., each soil sample (cylindrical with a $8 \mathrm{~cm}$ diameter and $25 \mathrm{~cm}$ depth) was collected and analyzed individually. At this stage, two points were sampled in each of the ten Terrain Components (modelling unit of the WASA-SED model) studied, totalling 20 soil samples in four hillslopes (H1, H2, H3 and H4, see Figure 2).

In the second stage of the research, a composite soil sampling procedure (hereafter named CSS) was adopted, in which six soil samples (of dimensions similar to those previously mentioned) located in the same modelling unit (Terrain Component) were mixed and analyzed as a unique sample. At this stage, hillslope $\mathrm{H} 5$ was studied with five Terrain Components, totalling five composite soil samples analyzed (one in each Terrain Component).

Due to the high variability observed on the reference ${ }^{137} \mathrm{Cs}$ inventories (see section Results and Discussion), and the different soil sampling procedures adopted, four simulations were performed to convert ${ }^{137} \mathrm{Cs}$ measures into soil redistribution rates (details on Table 2).

On simulation 1, a reference inventory of $27.6 \mathrm{~Bq} \mathrm{~m}^{-2}$ was adopted, based on the mean value estimated for the study watershed. However, sample R3 is much different from the other ones concerning the total inventory and its vertical distribution. Such characteristic may be related to some site specific feature and, therefore, this sample may not be representative of the reference over the entire watershed. Therefore, simulation 2 was carried out, with a reference inventory of $15.6 \mathrm{~Bq} \mathrm{~m}^{-2}$ based on the mean value of samples R1 and R2. On simulation 3, inventory of sample R1 (18.7 $\mathrm{Bq} \mathrm{m}^{-2}$ ) was admitted as reference, since sample R2 is situated very distant (15 to50 $\left.\mathrm{km}^{2}\right)$ from the studied hillslopes and may be influenced by spatial variability of ${ }^{137} \mathrm{Cs}$ fallout. At last, simulation 
4, carried out for hillslope $\mathrm{H} 5$, was based on a reference inventory of $51.7 \mathrm{~Bq} \mathrm{~m}{ }^{-2}$, relative to that of sample R3, the one nearest to the studied hillslope and with the same soil type (latosol).

TABLE 2. Simulations to convert ${ }^{137} \mathrm{Cs}$ measures into soil redistribution rates

\begin{tabular}{ccccl}
\hline \multirow{2}{*}{ Simulation } & Studied & Soil sampling & \multicolumn{2}{c}{ Reference inventory } \\
\cline { 4 - 5 } & Hillslopes & procedure & Bq.m² & \multicolumn{1}{c}{ Description } \\
\hline 1 & H1, H2, H3, H4 & ISS & 27.6 & Mean value at the study area \\
2 & H1, H2, H3, H4 & ISS & 15.6 & Mean of samples R1 and R2 \\
3 & H1, H2, H3, H4 & ISS & 18.7 & Sample R1 \\
4 & H5 & CSS & 51.7 & Sample R3 \\
\hline
\end{tabular}

\section{RESULTS AND DISCUSSION}

Simulation of the Benguê watershed performed with the WASA-SED model over the period 1963-2008, indicates a spatial pattern of soil redistribution closely related to the watershed behaviour concerning runoff. As discussed by MEDEIROS et al. (2010), the central and northern sectors of the study watershed present shallow and easily saturated soils, generating higher runoff depths. As a consequence, lateral soil movement is more intense in that region. On the other hand, the west and south borders, as well as the vicinity of the watershed outlet, are situated above deeper and highly permeable soils. The lower sediment transport capacity on those regions produce lower soil redistribution rates.

Figure 2 shows the spatial pattern of accumulated soil redistribution from 1963 to 2008, according to the simulations performed with the WASA-SED model.

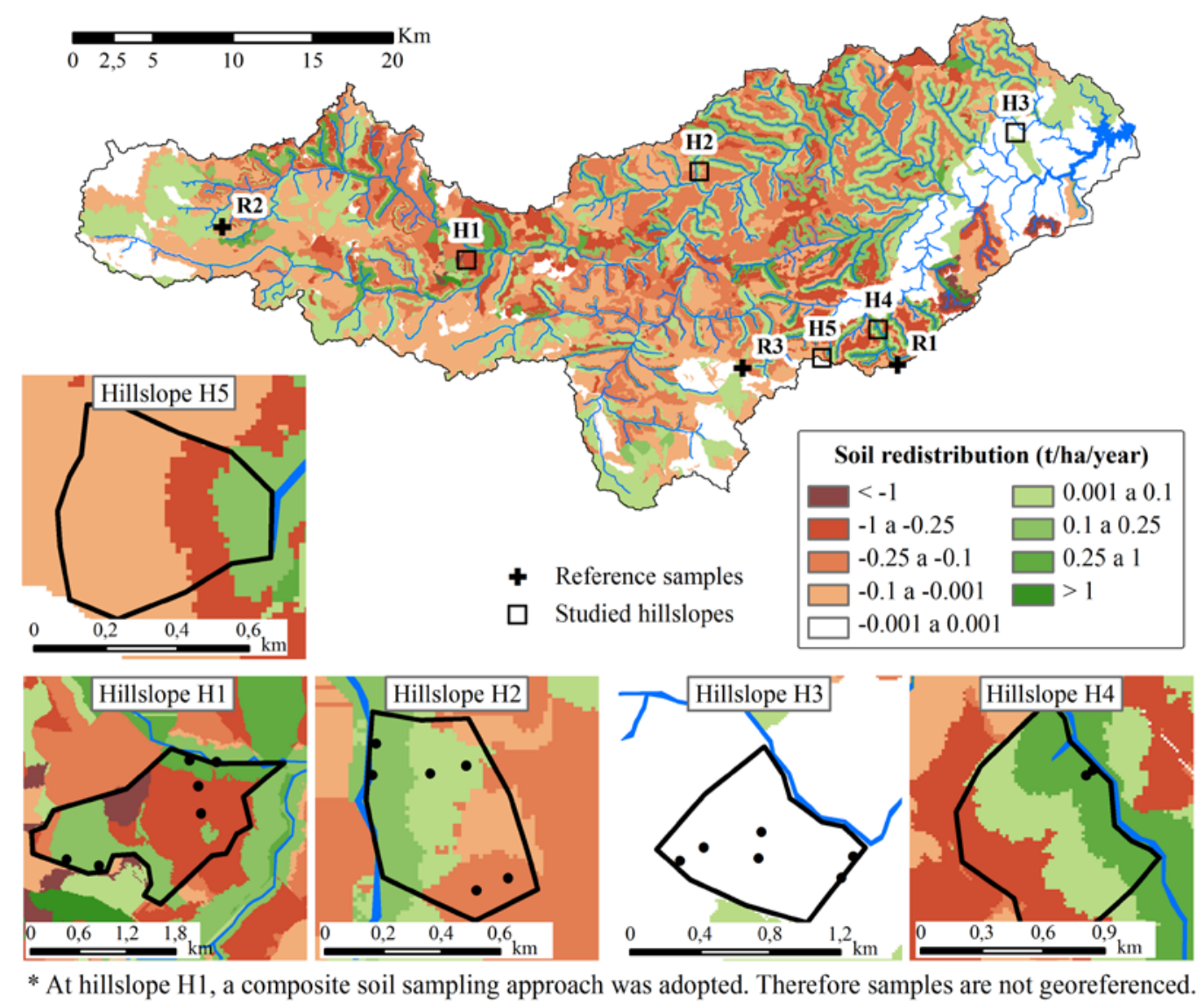

FIGURE 2. Accumulated soil redistribution (1963-2008), simulated with the WASA-SED model. 
Model validation at the watershed scale has been previously performed by MEDEIROS et al. (2010). In order to validate the spatially distributed results of the WASA-SED model, the ${ }^{137} \mathrm{Cs}$ technique was applied. The ${ }^{137} \mathrm{Cs}$ inventories at the sites expected to be reference presented high variability. For the reference soil samples, ${ }^{137} \mathrm{Cs}$ total inventory varied from $12.5 \mathrm{~Bq} \mathrm{~m}^{-2}$ (sample $\mathrm{R} 2$ ) to a maximum of $51.7 \mathrm{~Bq} \mathrm{~m}^{-2}$ (sample R3), i.e., a factor of over 4 times (Table 3). Mean ${ }^{137} \mathrm{Cs}$ inventory for the reference samples $\mathrm{R} 1, \mathrm{R} 2$ and $\mathrm{R} 3$ was $27.6 \mathrm{~Bq} \mathrm{\textrm {m } ^ { - 2 }}$. Considering the variability of the ${ }^{137} \mathrm{Cs}$ inventory among the three reference sites, establishment of the reference inventory must be a major source of uncertainty in this study.

In relation to its vertical profile, the ${ }^{137} \mathrm{Cs}$ inventory also presents high variability in the three reference sites, with depths ranging from $8 \mathrm{~cm}$ (samples R1 and R2) to $25 \mathrm{~cm}$ (sample R3) and different vertical distributions, as shown on Figure 3: ${ }^{137} \mathrm{Cs}$ decay along the profile on sample R1 and a more homogeneous profile on samples R2 and R3.

TABLE 3. ${ }^{137}$ Cs inventories in the reference sites

\begin{tabular}{cccc}
\hline Soil sample & Soil type & Depth of ${ }^{137}$ Cs detection $(\mathrm{cm})$ & ${ }^{137}$ Cs inventory (Bq.m $\left.{ }^{-2}\right)$ \\
\hline R1 & Neosols & 8 & 18.7 \\
R2 & Neosols & 8 & 12.5 \\
R3 & Latosols & 25 & 51.7 \\
\hline & & Mean reference: & 27.6 \\
\hline
\end{tabular}

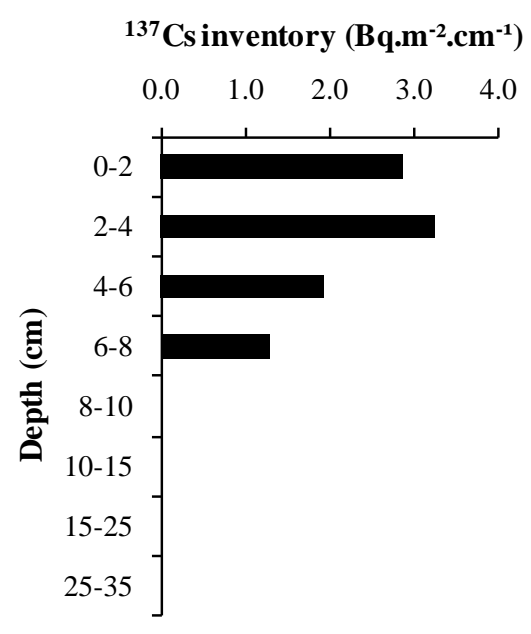

Total inventory: 18.7 Bq.m-2

a) Reference sample R1

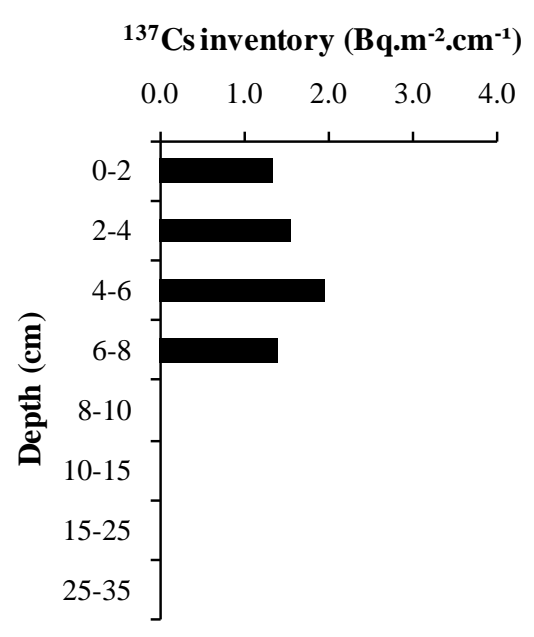

Total inventory: 12.5 Bq.m-2

b) Reference sample R2

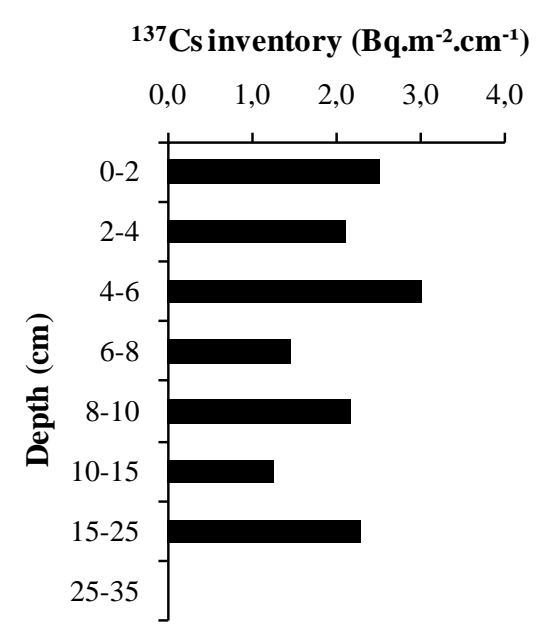

Total inventory: 51.7 Bq.m-2

c) Reference sample R3

FIGURE 3. Vertical profiles of ${ }^{137} \mathrm{Cs}$ inventories at the reference sites

Other finding concerning the ${ }^{137} \mathrm{Cs}$ reference in the study area is that inventories measured in the Benguê watershed are one order of magnitude lower than those observed in the South and Southeast regions of Brazil (BACCHI et al., 2003; ANDRELLO et al., 2004; CORRECHEL et al., 2006) and two orders of magnitude lower than inventories in Europe (e.g. RODWAY-DYER \& WALLING, 2010; PORTO \& WALLING, 2012). However, the reference inventory in the Benguê watershed seem to be in accordance with ${ }^{137}$ Cs inventories in the Northeast region of Brazil, e.g. those measured by ANTUNES et al. (2010) and SOARES NETO et al. (2009) on the Federal States of Pernambuco and Bahia, respectively. Table 4 presents estimations of the ${ }^{137} \mathrm{Cs}$ reference inventories at different sites in Brazil.

In Figure 4 it is observed that the ${ }^{137} \mathrm{Cs}$ inventories in Brazil decrease with lower latitudes and mean annual rainfall, as already discussed by other authors (ZAPATA \& NGUYEN, 2009) based 
on studies carried out in Europe. In addition to the fact that ${ }^{137} \mathrm{Cs}$ fallout was less intense in the southern hemisphere, such behaviour places the study region among those with the lowest ${ }^{137} \mathrm{Cs}$ reference inventories measured around the world.

TABLE 4. ${ }^{137}$ Cs reference inventories measured at different regions of Brazil.

\begin{tabular}{|c|c|c|c|c|c|}
\hline \multirow{2}{*}{$\begin{array}{c}\text { Location } \\
\text { (Municipality / } \\
\text { Federal State) }\end{array}$} & \multicolumn{2}{|c|}{${ }^{137}$ Cs ref. inventory. (Bq.m ${ }^{-2}$ ) } & \multirow[b]{2}{*}{ Latitude } & \multirow[b]{2}{*}{$\begin{array}{l}\text { Mean annual } \\
\text { rainfall (mm) }\end{array}$} & \multirow[b]{2}{*}{ Authors } \\
\hline & Measured & $\begin{array}{l}\text { Updated } \\
\text { to } 2011^{*}\end{array}$ & & & \\
\hline Aiuaba / CE & 27.6 & 25.8 & $6.5^{\circ} \mathrm{S}$ & 580 & This study \\
\hline Araripina / PE & 64.0 & 62.5 & $7.6^{\circ} \mathrm{S}$ & 712 & Antunes et al. (2010) \\
\hline Goiana / PE & 71.6 & 70.0 & $7.6^{\circ} \mathrm{S}$ & 1,754 & Antunes et al. (2010) \\
\hline Sertânia / PE & 95.5 & 93.3 & $8.1^{\circ} \mathrm{S}$ & 528 & Antunes et al. (2010) \\
\hline $\begin{array}{l}\text { Luiz Eduardo } \\
\text { Magalhães /BA }\end{array}$ & 28.6 & 27.3 & $12.1^{\circ} \mathrm{S}$ & 1,122 & Soares Neto et al. (2009) \\
\hline Campinas / SP & 272.0 & 242.4 & $22.2^{\circ} \mathrm{S}$ & 1,400 & Correchel et al. (2006) \\
\hline Piracicaba / SP & 418.7 & 348.3 & $22.6^{\circ} \mathrm{S}$ & 1,270 & Bacchi et al. (2003) \\
\hline Londrina / PR & 343.8 & 313.6 & $23.3^{\circ} \mathrm{S}$ & 1,588 & Andrello et al. (2007) \\
\hline Cambé / PR & 292.0 & 248.6 & $23.3^{\circ} \mathrm{S}$ & 1,615 & Andrello et al. (2004) \\
\hline
\end{tabular}

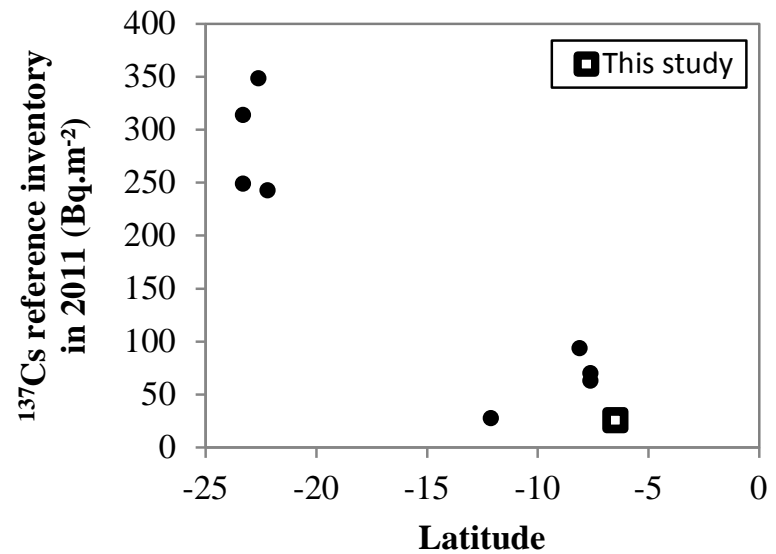

a) ${ }^{137}$ Cs inventories versus latitude

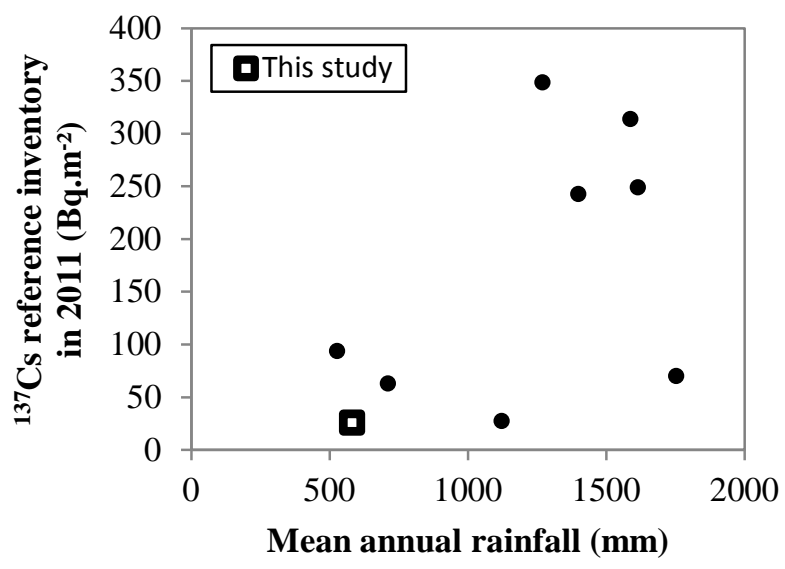

b) ${ }^{137} \mathrm{Cs}$ inventories versus annual rainfall

FIGURE 4. Influence of latitude (a) and mean annual rainfall (b) on the ${ }^{137}$ Cs reference inventories in Brazil.

Inventories of ${ }^{137} \mathrm{Cs}$ were also measured on the five studied hillslopes to compute soil redistribution and validate the WASA-SED model simulation in the Benguê watershed. Location of the studied hillslopes is presented in Figure 2.

Initially, comparison between the WASA-SED results and those indicated by the ${ }^{137} \mathrm{Cs}$ technique was performed qualitatively, i.e., assuming compatibility between the methods when both indicated the predominance of the same process of erosion or deposition. Results for hillslopes H1, H2, H3 and H4, in which the individual soil sampling was carried out, are presented on Figure 5.

The three simulations performed indicate a high dependence of the ${ }^{137} \mathrm{Cs}$ technique performance to the reference inventory. Simulation 1 (reference inventory of $27.6 \mathrm{~Bq} \cdot \mathrm{m}^{-2}$ - Figure 5a), resulted in a poor performance, with 25\% compatibility between the two methods for hillslopes H1, H2 and H4. Simulation 2 (reference inventory of $15.6 \mathrm{~Bq} \cdot \mathrm{m}^{-2}$ - Figure $5 \mathrm{~b}$ ) and simulation 3 (reference inventory of $18.7 \mathrm{~Bq} \mathrm{~m}^{-2}$ - Figure 5c), produced better results, with $67 \%$ compatibility both, for the same hillslopes. For hillslope H3, in which WASA-SED model estimated approximately null soil 
redistribution, the inventory variability among the sampling sites was high (up to 50\%). Quantitatively, results from the WASA-SED model and the ${ }^{137} \mathrm{Cs}$ technique presented great differences, up to two orders of magnitude.

The poor performance on the three simulations seems to be influenced by the concentrated nature of the samples, as opposed to the average estimates of the WASA-SED model in areas of up to hundreds of hectares. Thus, localized features, such as flow convergence or divergence, for instance, can substantially influence the estimate using radioisotopes, while the semi-distributed modelling is less affected by such characteristics, which should introduce another important source of uncertainty to the comparison of the two methods.

To minimize the effects of site-specific characteristics on the soil redistribution estimates using the ${ }^{137}$ Cs technique, a composite soil sampling (mixture of six samples) was conducted. Composite samples were collected in the five Terrain Components of hillslope H5. In that site, compatibility between the WASA-SED model results and the ${ }^{137} \mathrm{Cs}$ technique was $100 \%$, as presented on Figure 5d.

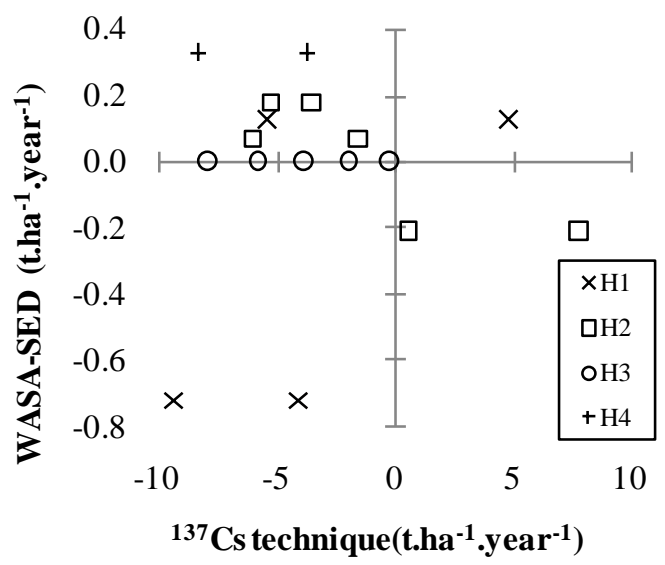

a) ISS - Ref. inventory: $27.6 \mathrm{~Bq} \mathrm{~m}^{-2}$

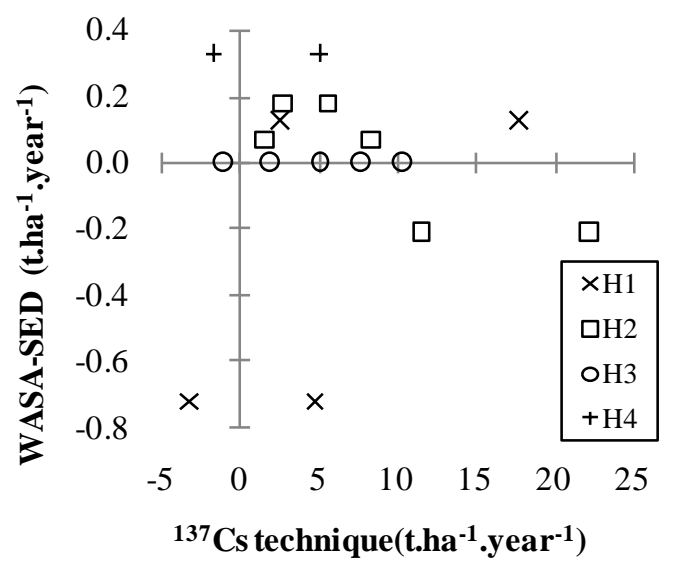

c) ISS - Ref. inventory: $18.7 \mathrm{~Bq} \mathrm{\textrm {m } ^ { - 2 }}$

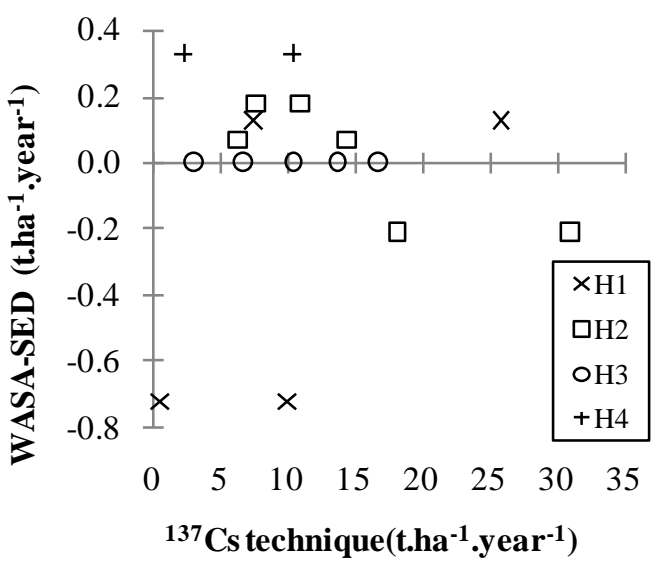

b) ISS - Ref. inventory: $15.6 \mathrm{~Bq} \mathrm{~m}^{-2}$

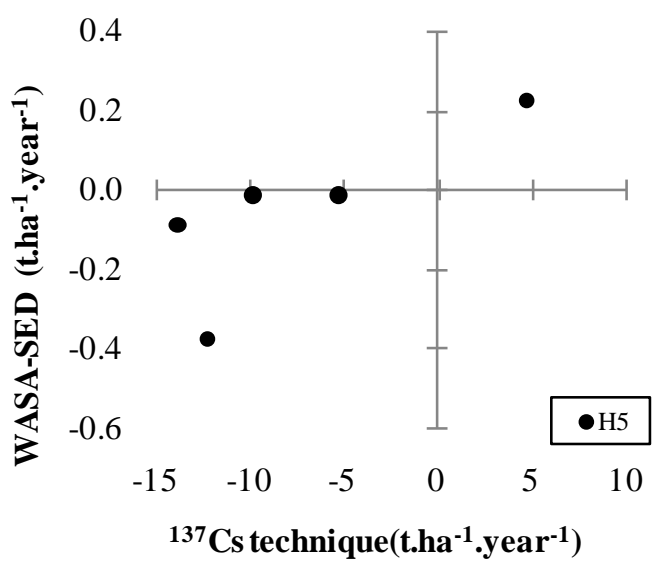

d) CSS - Ref. inventory: $51.7 \mathrm{~Bq} \mathrm{~m}^{-2}$

FIGURE 5. Soil redistribution estimated with the WASA-SED model and the ${ }^{137}$ Cs technique (ISS - individual soil sampling procedure; CSS - composite soil sampling procedure)

From Figure 5d, it is observed that, quantitatively, great differences still occur between the two methods for the composite soil sampling. Such deviation must be explained by additional sources of uncertainty concerning the ${ }^{137} \mathrm{Cs}$ technique:

- The lack of knowledge about the land use history in the Benguê watershed prevents a precise choice of the conversion model of ${ }^{137} \mathrm{Cs}$ inventory into soil redistribution rates. Moreover, the conversion models also present uncertainties: for the Proportional Model applied in this study, a 
reduction in the plough layer (admitted $8 \mathrm{~cm}$ ) due to different practices of soil tillage, for instance, approximates the estimations quantitatively;

- The low soil redistribution rates in the study area require a precise method for such estimations. However, the low measured ${ }^{137}$ Cs activity causes loss of accuracy in the laboratory analyses, which may prevent the technique to provided the appropriate accuracy in this specific case;

- The process of fine-particles enrichment (KERR et al., 2011) on the sediment transport along its pathway may introduce overestimation of the soil redistribution, since the ${ }^{137} \mathrm{Cs}$ is adsorbed preferentially to the fine fractions of the soil and the particles size distribution of the eroded sediment differs from that of the soil matrix.

Additionally, mathematical hydrological modelling is usually also imprecise. In this specific study, major sources of uncertainty concerning the simulations with the WASA-SED model are:

- Estimation of water and sediment fluxes along the watershed in the WASA-SED model includes the simulation of a significant number of processes, which may cause error accumulation during the transference of water and sediment between modelling units;

- Delineation of the modelling units involves the aggregation of different hillslopes on a single component with homogeneous characteristics, resulting in loss of information in the hillslope scale;

- Model parameterization was carried out keeping in mind the simulation of a meso-scale watershed (scale of $10^{3} \mathrm{~km}^{2}$ ). Therefore, the parameters adopted may not be able to represent the variability of watershed characteristics (such as soil and vegetation) at the scale of modelling unit ( scale $\leq 10^{0} \mathrm{~km}^{2}$ ), for which a validation is pretended with the ${ }^{137} \mathrm{Cs}$ technique.

\section{CONCLUSIONS}

Application of the ${ }^{137} \mathrm{Cs}$ technique to determine soil redistribution pattern enabled assessment of the WASA-SED model performance at the scale of modelling unit (scale $\leq 10^{0} \mathrm{~km}^{2}$ ). Regarding the qualitative analysis, the composite soil sampling, in contrast to the individual sampling technique, enhanced the performance from $67 \%$ to full (100\%) compatibility of the two methods. This improvement was attributed to the fact that the composite sampling reduced the influence of localized features (flow convergence or divergence, for instance) over the redistribution rates, which cannot be captured by the areal-mean estimates of the WASA-SED model.

Quantitatively, results of the ${ }^{137} \mathrm{Cs}$ technique and the WASA-SED model differed up to two orders of magnitude. Regarding the ${ }^{137} \mathrm{Cs}$ technique, the main sources of uncertainty identified were: I) Establishment of the reference inventory; II) Choosing the conversion model of ${ }^{137} \mathrm{Cs}$ inventory into soil redistribution rates; III) Precision required for the measurement of soil redistribution, which could not be met by the ${ }^{137} \mathrm{Cs}$ technique for specific conditions found on the study area, i.e. low ${ }^{137}$ Cs inventories; and IV) Representation of the fine-particles enrichment process on the ${ }^{137} \mathrm{Cs} /$ soil redistribution rates conversion.

With respect to the simulation of sediment fluxes with the WASA-SED model, uncertainty can be attributed mainly to: I) The large number of processes simulated, which can cause an error accumulation on the transference of sediment between modelling units; II) Loss of information in the hillslope scale during upscaling for delineation of the modelling units; III) Possible incompatibility between model parameterization at the watershed scale and representation of characteristics such as soil and vegetation at the scale of modelling unit.

The simulations performed for the Benguê watershed indicate the potential use of the ${ }^{137} \mathrm{Cs}$ technique for qualitative validation of modelling-based soil redistribution estimates. If measures are undertaken in order to reduce the uncertainties identified in this study, a quantitative validation may also be possible. 


\section{ACKNOWLEDGMENTS}

The authors would like to acknowledge CAPES (Coordenação de Aperfeiçoamento de Pessoal de Nível Superior) for the doctoral scholarship to the first author, CNPq (Conselho Nacional de Desenvolvimento Científico e Tecnológico), for the research grant to the second author, and IBAMA (Instituto Brasileiro do Meio Ambiente e dos Recursos Naturais Renováveis) for the support during field study.

\section{REFERENCES}

ANDRELLO, A.C.; APPOLONI, C.R.; GUIMARÃES, M.F. Soil erosion determination in a watershed from Northern Paraná (Brazil) using ${ }^{137}$ Cs. Brazilian Archives of Biology and Technology, Curitiba, v. 47, n. 4, p. 659-667, 2004.

ANDRELLO, A.C.; APPOLONI, C.R.; NASCIMENTO FILHO, V.F. Assessment of soil erosion by ${ }^{137}$ Cs technique in native forests in Londrina City, Paraná, Brazil. Brazilian Archives of Biology and Technology, Curitiba, v. 50, n. 6, p. 1051-1060, 2007.

ANTUNES, P.D.; SAMPAIO, E.V.S.B.; FERREIRA JÚNIOR, A.L.G.; GALINDO, I.C.L.; SALCEDO, I.H. Distribuição de ${ }^{137} \mathrm{Cs}$ em três solos representativos do estado de Pernambuco. Revista Brasileira de Ciência do Solo, Viçosa, MG, v. 34, p. 935-943, 2010.

ARAÚJO, J.C. de; PIEDRA, J.I.G. Comparative hydrology: analysis of a semiarid and a humid tropical watershed. Hydrological Processes, Chichester, v. 23 n. 8, p. 1169-1178, 2009.

BACCHI, O.O.S.; REICHARDT, K.; SPAROVEK, G. Sediment spatial distribution evaluated by three methods and its relation to some soil properties. Soil and Tillage Research, Amsterdan, v. 69, p. 117-125, 2003.

BRASIL. Ministério de Minas e Energia . Levantamento de recursos naturais - Projeto RadamBrasil. Volume 23, Folhas SB 24/25 (Jaguaribe / Natal), Rio de Janeiro, 1981.

BRONSTERT, A.; BATALLA, R.J.; DE ARAÚJO, J.C.; FRANCKE, T.; GÜNTNER, A.; LOPEZTARAZON, J.; MAMEDE, G.L.; MÜLLER, E.N. Integrated modelling of runoff and sediment fluxes across scales. In: R., DAS, B.S. INTERNATIONAL CONFERENCE ON FOOD SECURITY AND ENVIRONMENTAL SUSTAINABILITY, 2009, Kharagpur.

CORRECHEL, V.; BACCHI, O.S.S.; DE MARIA, I.C.; DECHEN, S.C.F.; REICHARDT, K. Erosion rates evaluated by the ${ }^{137} \mathrm{Cs}$ technique and direct measurements on long-term runoff plots under tropical conditions. Soil and Tillage Research, Amsterdam, v. 86, p. 199-208, 2006.

FRANCKE, T.; GÜNTNER, A.; BRONSTERT, A.; MAMEDE, G.L.; MÜLLER, E.N. Automated catena-based discretization of landscapes for the derivation of hydrological modelling units. International Journal of Geographical Information Science, London, v. 22, n. 2, p. 111-132, 2008.

KERR, J.G.; BURFORD, M.A.; OLLEY, J.M.; BUNN, S.E.; UDY, J. Examining the link between terrestrial and aquatic phosphorus speciation in a subtropical catchment: The role of selective erosion and transport of fine sediments during storm events. Water Research, New York, v. 45, n. 11, p.33313340, 2011.

MEDEIROS, P.H.A.; GÜNTNER, A.; FRANCKE, T.; MAMEDE, G.L.; ARAÚJO, J.C. de. Modelling spatio-temporal patterns of sediment yield and connectivity in a semi-arid catchment with the WASA-SED model. Hydrological Sciences Journal, Oxford, v.55, p. 636-648, 2010.

MEDEIROS, P.H.A.; ARAÚJO, J.C. de; BRONSTERT, A. Interception measurements and assessment of Gash model performance for a tropical semi-arid region. Revista Ciência Agronômica, Fortaleza, v. 40, n. 2, p. 165-174, 2009. 
MÜLLER, E.N.; GÜNTNER, A.; FRANCKE, T.; MAMEDE, G. Modelling sediment export, retention and reservoir sedimentation in drylands with the WASA-SED Model. Geoscientific Model Development, v. 3, p. 275-291, 2010.

PORTO, P.; WALLING, D.E. Validating the use of ${ }^{137} \mathrm{Cs}$ and ${ }^{210} \mathrm{~Pb}_{\mathrm{ex}}$ measurements to estimate rates of soil loss from cultivated land in southern Italy. Journal of Environmental Radioactivity, Amsterdan, v. 106, p. 47-57, 2012.

RODWAY-DYER, S.J.; WALLING, D.E. The use of ${ }^{137} \mathrm{Cs}$ to establish longer-term soil erosion rates on footpaths in the UK. Journal of Environmental Management, v. 91, n. 10, p. 1952-1962, 2010.

SOARES NETO, J.P.; SOUZA, N.M.; ANDRELLO, A.C.; APPOLONI, C.R. Atividade de ${ }^{137}$ Cs em amostra de solo sob vegetação natural na bacia hidrográfica do Rio das Ondas no oeste da Bahia. Magistra, Cruz das Almas, v. 21, n.2, p. 125-130, 2009.

WALLING, D.E.; HE, Q.; WHELAN, P.A. Using ${ }^{137}$ Cs measurements to validate the application of the AGNPS and ANSWER erosion and sediment yield models in two small Devon catchments. Soil and Tillage Research, Amsterdan, v. 69, p. 27-43, 2003.

WALLING, D.E.; HE, Q. Improved models for estimating soil erosion rates from Cesium-137 measurements. Journal of Environmental Quality, Madison, v. 28, p. 611-622, 1999.

ZAPATA, F.; NGUYEN, M.L. Soil erosion and sedimentation studies using environmental radionuclides. In: FROEHLICH, K. (Ed.). Environmental radionuclides - tracers and timers of terrestrial processes. Elsevier, 2009. 